UDC 82

DOI https://doi.org/10.32838/2663-6069/2020.3-2/41

Rustamkhanli T.

Institute of Literature named after Nizami Ganjavi

\title{
THE IDEA OF INDEPENDENCE IN THE LITERATURE OF THE REPUBLICAN PERIOD
}

At the beginning of the twentieth century another idea came to Turanism, and we can say with full responsibility that Azerbaijan has never experienced a rich cycle of ideas as in the early 20th century. The Azerbaijani literature showed the greatest heroism in fostering a sense of identity to the nation by not only competing with the political power of Azerbaijan, but also struggling for its independence. Azerbaijani literary criticism and study of literary also went through a long way in the Republican Period. Generally, most intellectuals of Azerbaijan at that time, along with the state building, wrote articles, books and published them in European countries to promote Azerbaijani literature, culture, art, history and ethnography. The Azerbaijan Democratic Republic has brought independence and freedom to the people, causing a revolutionary leap in public consciousness, morality, literature, art, and culture and though the most totalitarian regime in the world turned on all repressive machines, it could not erase it from memory. Though the written books, newspapers and articles were burned and destroyed, the seeds of independence that sank into hearts and minds raised again and led to the Independent Azerbaijan Republic. No matter how deep and ancient the history of the idea of national independence of the Azerbaijani people is, its history of research is much shorter. As we have already mentioned, the 70-year break in tradition and inheritance has become a serious obstacle to the study of the history of our independence. The followers of Azerbaijani independence in the works written by them in Turkey, Germany, and France using the words of Azerbaijan and independence as synonyms, engraved these ideas in people's memory which become the driving force of the national Self-consciousness. It is true that during the Soviet period their literary, scientific, and publicist activities and research on our literature were often ignored or subjected to biased and prejudiced criticism. However, many famous scholars have applied to the creations of emmigrated scholars during Soviet times.

We come across the concept of early independence in ritual and ceremonial songs related to religious beliefs, myths and legends, in oral literary examples, especially in poetic texts inspired by the people. "The aspiration of the ideas of national independence and the stage before the establishment and collapse of the Azerbaijan Democratic Republic did not cover a long period of history. But the contributions made by that time to our understanding of history, literature, culture and statehood were of one or two hundred dimensions. It is because of this greatness that this history is forbidden to us for seventy years and its ethnical memory, scientific and philosophical thinking, national self-consciousness, and ethical values are removed from the pages of history in such a unified and systematic way for many millennia. Thus, the end of the Azerbaijan Democratic Republic and the establishment of the Soviet Empire is considered to be the beginning of the 20s of the last century. The creators of the twentythree months Republic and people who carry it on their shoulders were marked as traitors of their homeland, the documents reflecting that period were forged, and the history was falsified for seventy years. All this led to the emergence of new themes and content in the literature of the Azerbaijan Democratic Republic, the emergence of distinct tendencies and styles around the idea of independence, and the development of romanticism along with the critical and enlightened realism. Let's look at the themes of that time: the Hymn of the three-color flag of independent Azerbaijan, the love for the national state, the protection and liberation of Azerbaijani lands from the Armenian occupation, the concerns about the fate of independence and many other issues.

Key words: Republican Period, poetry, struggle for independence, patriotism, national movement, national ideology, literary criticism.

Introduction. Literature has always been the carrier of the idea of independence, the most perfect form of public consciousness that ensures its succession, transmitted from generation to generation, and directly serves to revive national consciousness, without undermining the ideals of independence and sovereignty. State thinking, administrative and social institutions, and independent political units 
are based on the idea of independence, which is based on the literature, and comes true in the struggle for it. Today, the independent, sovereign Azerbaijan is the product of the idea of independence, which was formed first in literary and cultural thought, then sat in national consciousness and ensured national unity in the nation's struggle against the Empire, freedom and sovereignty. The literature in the period of ADR is not only a chronicle of that period, but also a great achievement in the historical assessment of events. Much work has been done in the study of the literature of this period, especially of the independent literature, including both the immigrant literature and the life and work of the repressed artists. However, we must admit that the literary and cultural understanding of our national independence history has not been systematically and coherently investigated, either during this period or in the background of great history or the Soviet era.

The purpose and objectives of the research topic. The main purpose of the research is to study the artistic and aesthetic genesis of the idea of national independence, to trace and study its historical development path. The main purpose of the research is to achieve the value of literature as a culmination point of the idea of national independence to an independent state and to develop a scientific-theoretical platform for transferring this idea to the future generations through literature.

Scientific novelty of the research. The national idea expresses the purpose and essence of its existence now and in the future, taking into account the ethnos of each ethnicity - the history of the people, the nation, and the experience of other nations. A growing generation based on the idea of national independence promoted by all types of literature and culture is fueled by a sense of patriotism, a feeling of love for the country, and a willingness to act in the protection and prosperity of its borders. The idea of national sovereignty ensures that the nationalliberation movement becomes its national ideology. Only the independence of the Azerbaijani people, the establishment of the independent Azerbaijan state, namely, the revival of tradition and inheritance principle, helped to resolve historical injustices in this area, to study nationalist ideological issues in the light of national consciousness, to explore the historical stages of artistic understanding of national consciousness. In this article, the concept of national independence has been studied and evaluated internationally as well as in the interpretation of Azerbaijani thinkers, prominent figures of literature and art.
Methods and sources of research. The theoretical-methodological basis of the research is the historical-comparative and descriptive method. The object of the research is the Azerbaijani oral literature, the system of primary religious and ethnic beliefs, canonical texts, classical literature, modern literature, emigrant scientific and artistic ideas, modern literary samples, studies of Azerbaijani and European scientists, and goals of humanities. As the idea of independence of the people dates back to the time when its original conscience was formed and the problem was examined in the context of the literary-historical development of Azerbaijan, the materials of the Oghuz-Turkic period and the South Azerbaijani literature and history were also the objects of the study.

A review of recent researches and publications. The idea of national independence is a national status that includes the whole system of values that the Azerbaijani people have dreamed of, struggled for, and historically realized. Thus, no matter how complex, difficult and lucrative were the people's idea of independence and efforts for it, all its details kept their traces, codes, signs in verbal art, material and spiritual culture and folklore. Although the state structures of a nation which forced the powerful states in a vast territory from Afghanistan to Anatolia and the Caucasus to account for itself, later its structures were disintegrated as a result of various treachery, but its idea of independence and struglle for it has been accompanied by a great history, passed on from generation to generation. At the beginning of the twentieth century, under the leadership of Mammad Amin Rasulzadeh, the people who regained their independence under the Azerbaijan Democratic Republic, proved their eternal commitment to independence by raising the banner "will not fall again". If we take into account the history of the Soviet Empire's struggle against the independence of Azerbaijan in the 20th century, with the release of the first and the last two decades, we cannot be surprised at the bloody wars that have followed the nation's independence and how it has been survived. The independence of Azerbaijan, which took place for the second time in the twentieth century as a result of Heydar Aliyev's rescue mission, allowed us to shed light on the great path our people have today, to explore its artistic and philosophical essence, and to revive the tradition of exploring artistic ideas of independence. Such authors, as Yashar Garayev ("History: Near and Far"), Elchin ("Literary Process: Death or Destiny"), Isa Habibbayli ("From Socialist Realism to National 
Independence"), Shirindil Alanyanli, Nikpur Jabbarly Immigration and Classical Heritage"), Vagif Sultanli (monograph "Azerbaijan Emigration Literature", collection of articles " Horizons of Freedom", "The literary World of Mohammad Amin Rasulzade", "The traveler of Heavy Path" and many other investigations), Alkhan Bayramoglu (The Literature during the Azerbaijan Democratic Republic), Vilayat Guliyev ("Agaoglu's"), Shamil Gurbanov ("Mammad Amin Rasulzade", "Nariman Narmanov's World"), Nasiman Yagublu ("Mohammad Amin Rasulzadeh"), Teymur Ahmadov ("Nariman Narimanov's Creative Way"), Huseynoglu ("I Live with Literature"), Nikpur, Badirkhan Ahmadov ("History of Azerbaijani Literature of the 20th Century"), Aybaniz Aliyeva-Kangarli ("Literature Issues in the Azerbaijan Newspaper (1918-1920)"), Ramiz Gasimov and Zulfiya Ismail ("The Concept of National Thinking and Azerbaijani Ideology in Azerbaijani Literature"), H. Baykara ("History of struggle for Azerbaijan's Independence") has done a great deal of work on these subject. In addition, we cannot ignore the works of prominent literary scholars dedicated their works to the study of the idea of independence, who are engaged in the study of the Azerbaijani literary arm of emigration literature. In fact, at the time of the Soviet repression, when the Bolshevik socialism was embroiled in a new world system that was out of reach, the ideology of our literature's independence came from the hard work of these writers and scholars. The political emigration of the twentieth century has been very productive and effective in the course of nearly seventy years (1920-1991) in the study and promotion of our rich folklore, classical and modern artistic heritage, and has initiated a wide range of problems in the history of national literature, created an emigration literary criticism, an important part of our literary-theoretical thought.

Presentation of the main material. Since the beginning of the second half of the 19th century, the national independence movement has played an important role in the national self-determination of the people of Azerbaijan, the consolidation of the idea of national independence in the public consciousness, the transformation of independence and freedom into national ideals. At the same time it laid the foundation for a political movement that flourished from the beginning of the twentieth century, and has emerged as a fact of struggle against imperial slavery. Hasan bey Zardabi's efforts to educate the nation resulted in the launch of three major tasks at the beginning of the twentieth century: 1 . The liberation of the people from the feudal bondage and ignorance; 2 . The liberation of the people from imperial bondage; 3. Determination of the basic principles of the ideas of national statehood.

On May 28, 1918, the Azerbaijani people achieved such a statehood that it could be considered a miracle not only for the East but for the West itself. The Azerbaijani People's Republic declaring independence in Tbilisi, soon moved to Ganja and the ancient Ganja became the first capital of the Republic. The ADR could only move to today's capital on September 17, when Baku was freed from the Armenian-Dashnak forces. The name of the founders of the Republic was known to the people long ago. From the declaration of independence until June 18, 1918, the role of parliament was still carried out by the TemporarP National Council, which was established on May 27 of that year and headed by Rasulzade. On December 7, 1918, the first Speaker of the parliament was elected A.M. Topchubashov, his deputy H.B. Agayev and his secretary Rahim Vekilov. Its main staff consisted of 44 members of the former National Council and 36 Muslim deputies from cities and accidents moved to parliament throudh the line of former national committees. Ideologists of the Republican era and the poetry of this period wanted the banner to hang over the Turan world as a whole. According to Tehran Alishanoglu, the dye of the flag, which is a symbol of modernity, has also embarked on a mission to carry Turkish and Islamic values. [1]

In his article "Literature and Repression" Professor Badirkhan Ahmedli truthfully called the personal approach to assessing the bloody events of the thirties as a justifiable approach and emphasized the importance of research as a political, historical, and spiritual fact, not a personal, literary and national event. The steps and actions taken in this area are not aimed at individuals, but are aimed at the nation's spiritual, cultural historical and cultural genocide; magnificent material and cultural monuments are destroyed, ancient mosques are demolished, monuments are destroyed, valuable books and manuscripts are burned. All this should have resulted in the eradication of the nation's idea of national independence [14]. The poets aim to awaken conscience and call the people to mobilize around the flag of independence in the days when the one-year flag of the Republic is celebrated. The poems of the poet are highly appreciated by Mammad Amin Rasulzadeh, Mirzabala Mammadzadeh, Ahmad Djafaroglu and others, and have been called "poems of independence" [7, p. 8]. In his article, A. Djafaroglu wrote that his poems were 
on the lips in Istanbul [2]. In his work "Modern Azerbaijani Literature", M. Rasulzadeh states, that Gultakin who lived and worked in emigration was not alone: “... There were other poets with Gultakin who lived in national emmigration and praised the ideas of country. We can show among them such writer, as Sanan and Yay;dj;1; Karim [9, pp. 81-82] Many of the poems in the book provide a realistic and symbolic description of the tragedies experienced by ethnic people in the Siberian deserts, known as the "icy hell" with the aim of uncovering the essence of the Bolshevik's invasion.

The Azerbaijani People's Republic, along with restoring ancient traditions of statehood in accordance with the genetic memory, ethnic-cultural values and national-spiritual practices of the nation and mobilized the arts and literature to express the ideology and idea of independence, bringing democratic, legal principles and, most importantly, the concept of people's power to the country life. In 1917-1918, literature was the first light to the darkness, an expression of the nation's joy and excitement. Mammad Amin Rasulzadeh wrote in his article "Modern Azerbaijani Literature": "Literature translates to this excitement, lives in the excitement and joy of approaching national independence days, expressing great hope in all its sensitivity" [10, p. 54]. In the article, Rasulzade particularly noted the literary activity of the poet Aliyusif, "who died in emigration in the remote tundra of the cold Siberia, not be able to continue the brutal torture of the Soviet executioners".

At that time, the Azerbaijani literature showed its greatest heroism in the struggle for national identity through the struggle not only with the political power of Azerbaijan, but also for its independence. Mammad Amin Rasulzade, who accurately evaluated the role of literature in the engraving the ideology of independence in the national consciousness, wrote in an article entitled "The Day of Salvation" in 1919: "It is known that literature is the act that spills the seeds of nationalism and independence into the hearts of the nation. O lyred poets and writers of the nation! Follow the deeds of the nation, their motives and purposes, and instill in their minds the love of the nation, the love of the homeland and the love of independence" [4, p. 79]. Certainly, it was not a possible matter of order, decision or decree bringing the idea of national independence into the minds of those people, who had been living in captivity of the empire from time to time, whose consciousnesses were distorted by the ideological and thought-provoking invaders. First of all, the seeds of love and freedom were to be planted into the hearts.
In this regard, MA Rasulzadeh wrote a very general summary: "Freedom and independence are achieved through literature and art, not by the main threads" [5, p. 14]. The meeting of the "Green Pen" literary union held on August 26, 1919 in the Parliament building, the Rasulzadeh's participation and his speech there, was also a sign of the national state's concern for literature and literary figures [4, p. 80].

The short-term activities of the ADR and its great work were designed to bring about fundamental changes in the national landscape - the transformation of medieval Azerbaijan into the modern world. Declaration the Azerebaijani language as the state language, expansion of the national press, establishment of Baku State University, establishment of the Azerbaijan State Theater, various societies and associations, etc. meant that the ADR's effective activities were focused on strategic objectives. In his article "The Idea of Renaissance in the Period Of People's Republic: Formation of Literature, Language and Culture" Yashar Garayev rightly referred to this period as the culmination of literature: "The Azerbaijani literature, which has been dating for hundreds of years before Islam, has re-established itself with Islam and has reached a new phase in the nineteenth-century within the framework of WestEast, has been coming to its final period after the three previous literary periods (its twentieth century) and reaches its peak - the years of the Independent Azerbaijani State - 1918-1920" [6, p. 155]. In the Republican Period, poetry was more successful than prose and drama [8, p. 11]. Muhammad Hadi, Hussein Djavid, Abdulla Shaig, Djafar Djabbarli, Ahmed Djavad, Umgülsum Sadigzadeh, Ali Yusif and others at this time by calling poetry the bearer of the idea of independence, they called upon the people to remain in the protection of this divine blessing. In general, the poetry of the Republican Period is summarized by researchers in terms of topics and problems: "1. Democracy, independence, freedom, and impressions of these attributes, 2. Poetry, which is far from national thinking and do not sound as a matter or issue" [11].

As we know, On November 9, 1918 the government of the Azerbaijan Democratic Republic (ADR) first enacted an order regarding the tricolor state flag. That order ruled to recognize the flag consisting of green, red and blue colors with a white crescent and an octagonal star as the national flag and it began to fluctuate for the first time in those days. This event immediately inspired the prominent Azerbaijani writer, poet and playwright $\mathrm{Dj}$. Djabbarly to create the poem "The Flag of Azerbaijan". 
In the early years of the expansion of the national movement, Jafar Jabbarly wrote plays such as the "Trablis War" and "Edirne Conquest", reflecting the revolutionary historical events in Turkey, the struggle of the Turkish people to protect their sovereignty and territory.

We see this idea in Abdullah Shaikh's poems as well. On the one hand, he calls on the nation to fight for independence, to protect the Azerbaijan Democratic Republic, on the other hand, reminding him that he is a Turk and expresses his regret over the inability of the Turks to join this day. His poems named "To Turan in Araz", "Turkish Nativity Group", "Why have you been late?", "In the face of waiting", "When the new moon is born" and "Marsh" reflect the struggle and the fighting spirit. One of the main activities of Ahmad Javad, who is also the author of poems such as "To the Turkish army", "To the martyrs", "To the Azerbaijani flag", "The flag of the border", "The Englishman", "Istanbul", "Baku says", and so on and known as an poet of independence is to write the ADR's anthem with Uzeyir Hajibeyov.

Ahmad Javad, who praised the Azerbaijan Democratic Republic from the early days wrote a poem "Why(What) Did You Create from" in honor of Memorial Day, on May 28.

Researcher Ali Shamil explained this: "M.A. Rasululzadeh, M.B. Mammadzadeh, A. Jafaroglu, Amin Abidi didn't even put a sign that could identify Gultaki's identity in order to protect them from the Soviet invasion. Therefore, they did not know in Azerbaijan, that Amin Abid was Gultakin. When Abid started to work, in the questionnaire and autobiography he filled out, he hid the fact that he wrote poems with his signature and cooperated with the "New Caucasian" and was in Erzurum and Gazvin [3, p. 8].

In poetry, Huseyn Javid, Ali Shovgi Mammad Said Ordubadi, Aligulu Gamkusar, Davud Agamirzadeh and other artists gave a general overview of the period when the Azerebaijani People's Republic existed. In prose these years were represented by the pen of wellknown writers, such as Jalil Mammadguluzadeh, Abdurrahimbek Hagverdiyev, Yusif Vazir Chamanzaminli,Abdulla Shaik, Seyid Houseyn, Tag1 Shahbazi. Jalil Mammadguluzadeh referring to the problems of female freedom, ignorance and feudalism ("The Consul's Wife", "The Beads of the Khan", "Butcher"), in his "The Lamb" story, he harshly criticized the negative moral qualities, the loss of national identity and the resistance of ignorant people to the freedom. Researchers say, that Hussein Javid's "Devil" tragedy "stems from the overall spirit and essence of the events that have taken place these years". On the other hand, in "the Devil" Hussein Javid is looking for ways to save Turan: "In this most poignant revolutionary work, the poet places a special emphasis on his main idea the idea of nationalism and Turkism: he expresses, that only a sword is not enough to save Turan with the words of hero of the poem:

The more powerful than the sword in Turan

Only culture, culture, culture! [10, p. 62].

Among the literary monuments of this period, we should especially note the play "Mother's Book", written by Jalil Mammadguluzadeh, which contains ideas of national unity and spiritual integrity. Azerbaijani literary criticism and study has also come a long way in the Republican Period. During this period, Seyid Hussein created the literary and scientific society "Green Pen". Mammad Amin Rasulzadeh, Hussein Javid, Seyid Hussein, Najaf Bey Vazirov, Uzeyir Hajibeyov, Abdulla Shaig, Ahmed Javad, Jafar Jabbarly, Salman Mumtaz, Ali Yusif and other intellectuals and artists united around this literary Society. Yusif Vazir Chamanzaminli also gave valuable works to Azerbaijani literary criticism. The monograph research "A Look at Azerbaijani Literature", published in Istanbul in 1919, is known for its scientific and theoretical significance.

Y. Chamanzaminli, who especially appreciated the heritage of Mirza Fatali Akhundov, wrote about it: "For the first time, the sense of nationalism has aroused in this writer, and the Renaissance Criticism begins with the works of Mirza Fatali".

One of the investigators of the Republican Period was Adilkhan Ziyadkhanli, the grandson of Javad khan Ziyadoglu-Qajar. Adil khan Ziyadkhanli, a prominent member of the Azerbaijani National Independence Movement, a state and socio-political figure, highly valued our classical heritage in his work "History, Literary and Political Information about Azerbaijan" published in 1919 and considered it important to carry out its research in the context of our national literature. As it is known, there were two different approaches to national heritage during this period: one group believed that the works of art not written in Azerbaijani were not the national wealth of the Azerbaijani people, but the other group, including Adil khan Ziyadkhanli, came from the opposite position and underlined the importance of the creativity of Azerbaijani writers into the national treasury regardless of their writing in Arabic and Persian [13]. Moreover, in the study of Adil khan Ziyadkhanly, "the analysis of the literary-cultural and socio-political environment in which the creativity of individual classics is linked has enabled to reveal regional shades of national literature as a whole" [12, p. 7]. 
Conclusions. Firudin bey Kocharli publishes "Literature of Azerbaijani Theater" in Tbilisi in Russian. F. Kocharli began his scientific career at a time when social and political tensions in Russia were exacerbated, and the desire for independence in the outlying regions was on the rise, as the central government weakened considerably. At the same time, the national consciousness in Azerbaijan was also strengthened by dramatics, prose, poetry and so on, the literature is enriched with ideas, and the number of newspapers and magazines published in our language has grown rapidly. Well-known scientist Firudin bey Kocharli writes about the systematic study of the history of Azerbaijani literature during this period. The "Azerbaijani Literature", "The Literature of Azerbaijani Turks" were written by him at that time. In his works, Yusif Vazir Chamanzaminli expresses his theoretical views on Nasimi, Abbasgulu Agha Bakikhanov, Mirza Fatali Akhundov, Kasim Bey Zakir,
Mirza Alekper Sabir and other poets, artists and their creativity. Generally, most intellectuals of Azerbaijan at that time, along with the state building, wrote articles, books and published them in European countries to promote Azerbaijani literature, culture, art, history and ethnography. We can point out Alimardan bey Topchubashov, Jeyhun Hajibeyli and others. In short, The Azerbaijani People's Republic,which existed only 23 months as Mammad Amin Rasulzadeh said, not only did the nation enjoy independence and freedom, but it also gave way to a revolutionary breakthrough in public consciousness, morality, literature, art and culture, that even though the most totalitarian regime had launched all repressive machines, it could not erase it from memory of the nation. Though the written books, newspapers and articles were burned and destroyed, the seeds of independence engraved into the minds and hearts raised again and led to the Independent Azerbaijan Republic.

\section{References:}

1. Alishanoglu Tehran. In the Light of Ideas of Modern Generation of Azerbaijanism, Literature Newspaper, June 13, 2015.

2. Djafaroglu A. Traces of Struggle for Independence in Azerbaijani Literature. "Azerbaijan Country Information" Journal, 1932, No. 8-9.

3. Djavanshir J. Rasulzade's Favorite Poet, the First "Korkut's Follower" of Azerbaijan. Adalat Newspaper, Baku, May 28, 2013.

4. Encyclopedia of The Azerbaijan People's Republic (The Azerbaijan Democratic Republic) : Volume I-II, I, Baku : Leader, 2004, 440 p.

5. Galiboglu E. The Republican Period of Azerbaijani Literature. The Halk Cephesi Newspaper, Baku, January 28, 2010, No. 16, p. 14.

6. Garayev Y. V. The Idea of Renaissance in the Period of People's Republic: Formation of Literature, Language and Culture / Garayev's Selected Works : 5 Vol, Volume V., Baku, Elm, 2016, 155-180 pp.

7. Gultakin-Amin Abid. The Icy Hell. Poems. Baku, "Gunesh" Publishing House, 1999, p. 8, 96 p.

8. Hasanov B., Mustafayeva A., Aliyev S., Verdiyeva N. Literature - 9: Methodical Manual for a Teacher on the Subject "Literature". Baku : "Baku" Publishing House, 2016, 223 p.

9. Rasulzade M. A. "Sayavush of Current Age", Ankara, 1989, p. 44-45.

10. Rasulzade M. A. Sayavush of Current Age, Modern Azerbaijani Literature, History of Modern Azerbaijan. Youth, Baku, 1991, 112 p.

11. Sharifova S. Sh. Overview of the 20th Century Azerbaijani Literature, http: www.academia / edu / 11899224/

12. Shukurova G. V. The Great Happiness of the Century is the Literature in the People's Republic Period. 525th Newspaper, Baku, December 10, 2009, No 228, p. 7.

13. Ziyadkhanov A. A. Azerbaijan. Baku : Azerbaijan Publishing House, 1993, 176 p.

14. Bədirxan Ohmədov - Әdəbiyyat və repressiya URL: http://www.avanqard.net/index.php?action=static_ detail\&static_id $=55058$.

\section{РостамХані Т. ІДЕЯ НЕЗАЛЕЖНОСТІ В ЛІТЕРАТУРІ РЕСПУБЛІКАНСЬКОГО ПЕРІОДУ}

На початку XX століття до туранізму прийшла інша ідея, $і$ ми можемо з повною відповідальністю сказати, що Азербайджан ніколи не переживав такого насиченого циклу ідей, як на початку 20 століття. Азербайджанська література продемонструвала найбільший героїзм у формуванні почуття ідентичності у начїі, не тільки змагаючись із політичною силою Азербайджану, але йборючись за його незалежність. Азербайджанська літературна критика та вивчення літератури також пройшли довгий шлях у республіканський період. Загалом більщість інтелектуалів Азербайджану на той час, разом із державним будівництвом, писали статті, книги та публікували їх у європейських країнах для пропаганди азербайджанської літератури, культури, мистеитвва, історії та етнографії. 
Азербайджанська Демократична Республіка принесла людям незалежність $і$ свободу, спричинивши револючійний стрибок у суспільній свідомості, моралі, літературі, мистецтві та культурі, $і$ хоча найтоталітарніший режим у світі ввімкнув усі репресивні машини, він не міг його стерти з пам'яті. Попри те, що написані книги, газети та статті були спалені та знищені, насіння незалежності, яке заглибилось у серия та розум, знову піднялося та призвело до незалежної Азербайджанської Республіки. Якою б глибокою і давньою не була історія ідеї національної незалежності азербайджанського народу, історія ї̈ досліджень значно коротша. Як ми вже згадували, 70-річна перерва в традиціях та спадщині стала серйозною перешкодою для вивчення історії нашої незалежності. Послідовники незалежності Азербайджану у творах, написаних ними в Туреччині, Німеччині та Франиї, використовуючи слова «Азербайджан» та «незалежність» як синоніми, закарбували иі ідеї в пам'яті людей, які стають рушійною силою начіональної Самосвідомості. Це правда, щь за радянського періоду їхня літературна, наукова та публічистична діяльність та дослідження нашої літератури часто ігнорувались або зазнавали необ 'єктивної та упередженої критики. Однак багато відомих учених зверталися до творів учених, що емігрували ще за радянських часів.

Поняття ранньої незалежності ми зустрічаємо в ритуальних та обрядових піснях, пов'язаних із релігійними віруваннями, міфами та легендами, в усних літературних прикладах, особливо в поетичних текстах, натхненних людьми. «Прагнення ідей наиіональної незалежності та етап до встановлення та розпаду Азербайджанської Демократичної Республіки не охоплювали тривалого періоду історії. Але внесок того часу в наше розуміння історії, літератури, культури та державності мав один-двісті вимірів. Саме завдяки цій величі ия історія нам заборонена на сімдесят років, а ї̈ етнічна пам'ять, наукове та філософське мислення, національна самосвідомість та етичні иінності видаляються зі сторінок історії таким єдиним і систематичним для багатьох тисячоліть. Таким чином, кінеиь Азербайджанської Демократичної Республіки та створення Радянської імперії вважається початком 20-х років минулого століття. Твориі Республіки двадиять три місяиі та люди, які несуть ї̈ на своїх плечах, були позначені як зрадники своєі Батьківщчини, документи, що відображають ией період, були сфальсифіковані, а історія фальсифікована на сімдесят років. Все ие призвело до появи нових тем $і$ змісту в літературі Азербайджсанської Демократичної Республіки, появи чітких тендениій і стилів навколо ідеї незалежності, розвитку романтизму поряд з критичним і освіченим реалізмом. Давайте розглянемо теми того часу: Гімн триколірному прапору незалежного Азербайджану, любов до начіональної держави, захист та звільнення азербайджанських земель від вірменської окупачії, стурбованість долею незалежності та багато інших питань.

Ключові слова: республіканський період, поезія, боротьба за незалежність, патріотизм, національний рух, начіональна ідеологія, літературна критика. 